\title{
SERVICE GUARANTEES IN THE CONTEXT OF PROFESSIONAL SERVICES - CASE OF LAW FIRMS
}

\author{
MAREK GNUSOWSKI \\ Poznan University of Economics and Business, Poznań, POLAND \\ e-mail: marek.gnusowski@ue.poznan.pl
}

RECEIVED
ACCEPTED
JEL
CLASSIFICATION

KEYWORDS

ABSTRACT
15 September 2017

12 December 2017

L84, M31, 014

service guarantees, service marketing, professional services, law firms, case study

This article focuses on the benefits of guarantees offered by law firms, as professional service firms. Can law firms even offer service guarantees, since lawyers can't guarantee an outcome? This research expands the current knowledge on service guarantees in the context of legal services. It proves that service guarantees are considered effective means for service firms to attract and retain customers and gain a competitive edge in the marketplace. This article integrates two approaches - conceptual and empirical. The conceptual discussion of the paper draws attention on existing research and integrates the professional services (legal) and service guarantees domains. The empirical part of this study announces two examples of law firms from real business world, which are innovators in introducing their ways of doing business by service guarantees.

\section{Introduction}

Guarantees on products, have become commonplace. But guarantees in professional services are not that popular yet. The main aim of this paper is to clarify what researchers have learned about service guarantees and what are their main benefits. The study is divided into three parts. The first one describes the nature of professional services. The second part includes theoretical context of service guarantees, and benefits of offering them both for firms and clients. In the third part, the results of empirical research (case study logic) are presented.

\section{The nature of professional services}

The marketing of professional services is a growing area of interest in both academic and professional press (Bloom, 1984; Jones, 1997; Thakor, Kumar, 2000; Hausman, 2003; Reid, 2008). The goal of this part is 
to develop theoretical propositions that can help further understand the complex phenomenon of professional services In general, services such as accounting, legal, and medical services are commonly cited as the traditional professions. Gummesson (1978) identified a series of the following criteria that distinguish professional services: service should be provided by qualified people, be advisory, focus on problem solving, the service should be an assignment from the buyer to the seller, and the professional should be independent of suppliers of others goods and services. The professions are often distinguished in terms of possessing systematic theory and professional authority, being sanctioned by the community, being governed by an ethical code, and exhibiting a professional culture (Thakor, Kumar, 2000). Moreover, the professions offer services that are highly complex, intangible, highly customized, and are created and delivered by highly qualified personnel, over a continuous stream of transactions or service encounters (Jones, 1997; Thakor, Kumar, 2000). In fact, owing to its high-degree of customer contact, as well as the level of individual judgment required by the professional, this form of service is considered the most intangible (Jaakkola, Halinen, 2006). Knowledge intensiveness is another distinguishing characteristic of this business, where knowledge has a role both as a resource and as a service sold to clients (Smedlund, 2008). Professionals offer their clients a sophisticated, knowledge-based expertise (Maister, 1993), and the relationships these professionals create with their clients are the medium through which they impart this expertise to solve their clients' problems (Reihlen, Apel, 2007; Walsh, Gordon, 2010). In professional services, as in most services in general, the reason for the highlighted role of the client is related to the fact that the client provides significant inputs into the production process, making the success of the service heavily reliant on client input (Rogozinski, 2000).

\section{What is a service guarantee?}

Service guarantees have the potential to transform service organizations. Despite their high potential value and some very successful examples they remain the exception rather than the rule for service organizations. No clear consensus exists for a definition of the service guarantee construct (Hogreve, Gremlin, 2009, p. 324). First of all, Hart, Schlesinger, and Maher (1992, p. 20) expressed that, a guarantee is simply a statement explaining [what] the service customers can expect (the promise) and what the company will do if it fails to deliver (the payout). Baker and Collier (2005, p. 197) stated that, a service guarantee promises the customer that if the service delivery system does not meet certain performance standards, the customer is entitled to an economic and/or noneconomic payout. Similarly, Sum et al. (2002, p. 348) advocated that "A service guarantee is a promise by a company to compensate the customer in some way if the defined level of service delivered is not duly met." This approach was extended by Owen (2004, p. 58), who mentioned, that a satisfaction guarantee is an affirmation by the seller that assures buyer satisfaction, promising to take the buyer to a pre-purchase state (e.g., replacement or money back) rather than offering any changes to the product if the seller is not satisfied, whether or not the product performed as intended by the seller or as wanted by the buyer." Also, Björlin-Lidén and Skalén (2003, p. 39) has taken a similar approach - to guarantee a service simply means to present measures for service quality and to offer compensation in case when the promised quality is not achieved. On the other hand, Kashyap (2001, p. 2) noticed, that a guarantee contains two typical elements: a service promise or pledge that expresses the firm's willingness to engage in behaviors considered desirable by its customers and a compensation offer in case of service failure. The definition adopted in this paper was designed by Hogreve, Gremlin (2009, p. 324) - a service guarantee is an explicit promise made by the service provider to (a) deliver a certain level of service to satisfy the customer and (b) remunerate the customer if the service is not sufficiently delivered. 


\section{What Makes a Good Guarantee?}

A good guarantee should be simple and unconditional. If client requests a guarantee, organization should quickly respond. Moreover, entire organization should embrace the operating philosophy dictated by the use of guarantees. Employees should know the clients well enough to judge when a guarantee is helpful and when it isn't. At the same time, performance of the service process should be carefully monitored to avoid surprises. This should help limiting the number of "called in" guarantees (McLaughlin, 2005). Of course, before deciding to offer a service guarantee a company must be sure that the level of service quality that it is planning to guarantee is generally achievable (Hays, 2004). Company that offer a guarantee do show clients that, they are willing to share the risk, making the relationship a true collaboration.

\section{The benefits of offering service guarantees by professional service firms}

There are several benefits of service guarantees, both for clients and firms. When implemented appropriately, service guarantees can improve service quality, customer satisfaction and customer loyalty. There are three main categories of benefits: through marketing, employee motivation and learning from its mistakes (Hays, 2004).

1. Marketing - service guarantee can have both a proactive and reactive marketing impact. Proactive marketing reflects the company's ability to attract new customers. A company can use a service guarantee to proclaim the reliability of their high-quality service and, thus, attract new customers. It puts firm a as reliable - all companies offer "great service" but not many can back it up. Without a guarantee to back up those words, though, clients just perceive them as empty promises. It also allows companies to charge a price premium for reducing (or removing) customer risk- it there are no excuses, the customer may pay way more (Baker, 2008). Reactive marketing reflects a company's ability to increase customer loyalty and customer satisfaction through customer retention and recovery efforts (Hays, 2004). Moreover, only few professional service providers are providing a guarantee of promised results, so service guarantees are important, competitive differentiator (McLaughlin, 2005). It's an enormous marketing advantage.

2. Employee motivation - another benefit of offering a guarantee is that it can enhance a firm's culture of service quality. It forces company to learn customer's expectations and to manage them. At the same time, it focuses entire firm on the customer's expectations, and allows employees to do what it takes to exceed them (Baker, 2008). Customer perceptions of quality are shaped by the courtesy, empathy and responsiveness of service employees. Motivated employees with a clear vision of the importance of service quality are more likely to provide customers with a high-quality service experience. The guarantee makes a powerful statement about the importance of service quality to the company and empowers employees to ensure customer satisfaction (Hays, 2004). Empowerment of service workers may help reduce role stress and emotional labor (Chebat, Kollias, 2000).

3. Learn from mistakes - with a guarantee in place, firm and client should reach precise agreement on project objectives, outcomes and measurements of satisfaction. This level of rigor leads to a less ambiguous proposal, a more rational price and better marching orders for those working on the assignment (McLaughlin, 2005). However, service guarantees incentivizes the customer to complain, which is a good thing, because a complaint is a second chance to repair the relationship. Moreover, encouraging and rewarding customer complaints provides feedback on service quality. A company offering a service guarantee is forced to 
compensate customers for low-quality service. By "punishing" the company for less-than-quality service, they prompt the company to find the root causes of service problems and to improve service quality (Hays, 2004). It also forces company to do a better job in customers selection and deselection.

\section{Methodology}

For empirical research, a case study logic (based on observational research - "nonparticipant" observation), which has grown in reputation as an effective methodology (Yin, 2014) was applied. Multiple sources of evidence were utilized. These include: company websites, business plans, magazine and newspaper articles, slide-shows etc. Hence, the organizations were studied in their real-life contexts (Eisenhardt, Graebner, 2007). This paper profiles two examples of contemporary law firms in real business world and how they have successfully benefited from implementing service guarantees. To the best knowledge of the Author, there are no examples of law firms in Poland offering unconditional full satisfaction guarantee strategy, therefore both of described firms operate in the US. An unconditional guarantee contains few if any provisions and states in essence "your satisfaction guaranteed or your money back" (McCollough, 2010). Both of the law firms may be considered as innovators in introducing their ways of doing business concepts that have worked in other industries, but remain rare in professional services context. Applying observational research may also help predict future trends.

\section{Resulls}

In fact most of law firms (ethical and conscientious professionals) do provide service guarantees. However, just few of them explicitly advertise it as their marketing strategy. Ungaretti \& Harris LLP, a firm from Chicago claimed to be the law first firm to offer service guarantee (Baker, 2008):

We GUARANTEE that as a client of Ungaretti \& Harris you will receive COST-EFFECTIVE legal services delivered in a TIMELY manner. We promise to INVOLVE you in strategic decisions and to COMMUNICATE with you regularly. We cannot guarantee outcomes, but we do GUARANTEE YOUR SATISFACTION with our SERVICE. If at any time Ungaretti \& Harris does not perform to your satisfaction, we ask that you inform us PROMPTLY. We will then resolve the issue to YOUR SATISFACTION, even if it means reducing our legal fees.

Such an approach has been further developed by Denmon \& Denmon Law from Tampa, who not only assure their clients of highest standards of professionalism:

We have high expectations for the professionals that we work with. And you should have the same expectations for your lawyer. That's why we are proud to offer a $100 \%$ service guarantee to each and every one of our clients. Now, no law firm can guarantee favorable results for the client. That would be unethical. After all, there are factors outside of our control (Judges and Juries for example) that may affect the final resolution. But we can hold ourselves to the highest standards of professionalism and service. We can make sure that your calls and questions will be promptly answered. We can make sure that you are confident with us every step of the way. And we can make sure you are treated with respect and dignity in an otherwise terribly difficult time in your life.

But also offer 30 days guarantee: (Denmon, 2017) 
If at any time during the first 30 days of representation you are not satisfied with the service we are providing and want to hire another lawyer, we will refund $100 \%$ of your money. If during any month afterward you become unhappy with our service and want to leave, we will refund that month's worth of legal service fees, no questions asked. We will honor this guarantee at any time before your case or project is completed. And when you have retained another attorney, we will share your case file digitally with your new attorney so to make the transition as seamless as possible.

Both firms managers believe that they have the best approach to how handle cases. There are confident in how they treat their customers, through the course of representation:

This means frequent and open communication as well as transparency throughout the process. You will have access electronically to every Court pleading, Judge's order, and letters from opposing counsel in your case. But we also recognize that our clients need to have a lawyer and a firm that they feel comfortable will lead them through a dark patch in their lives and into a better place. And if it turns that we accepted your case but we were not the right fit, we want you to have the ability to switch gears and find a more suitable lawyer for your needs. We don't want you to feel "stuck" with us because you paid a fee or retainer in advance of the case. We want to shoulder some of the risk in this process with you.

\section{Conclusions}

As competition grows more fierce in the legal services industries, many firms are eager for any means to differentiate themselves from competitors and overcome client concerns about obtaining the highest value for the money. One of the most effective ways to affect customers perception of reliability is to offer an unconditional guarantee of satisfaction. For many firms, such a guarantee has proven to be a powerful tool for building market share, strengthening customer loyalty, and improving overall service quality (Hart, Schlesinger, Maher, 1992)

Although the success of unconditional service guarantees remains hard to quantify, it is not surprising that professional service firms would express interest in them. The findings from conceptual and empirical observations suggest that law firms can incorporate service guarantees into their work and relationships with clients. The successful law firms of the future will find ways to introduce their ways of doing business concepts that have worked in other industries (Schmidt, 2004). A service guarantee may be one such strategy.

While the study has supplied useful information about service guarantees in legal services context, the chosen method and limited number of exemplary law firms, are the source of a significant limitation, that must be acknowledged. There is very little basis for generalization of findings and conclusions. Moreover, applying a different or more robust methodology might address the research problem more effectively in a future study.

\section{References}

Baker, T., Collier, D. (2005). The Economic Payout Model for Service Guarantees. Decision Sciences, 36 (May), $197-220$.

Baker, T. (2008). Can Law Firm offer Service Guarantees? Retrieved from: http://verasage.com/blog/ask_verasage_can_law_firms_ offer_service_guarantees (23.5.2017).

Bloom, P. (1984). Effective marketing practice for professional services. Harvard Business Review, September/October, $102-110$.

Björlin-Lidén, S., Sanden, B. (2004). The Role of Service Guarantees in Service Development. Service Industries Journal, 24 (July), 1-20.

Chebat, J., Kollias, P. (2000). The Impact of Empowerment on Customer Contact Employees' Roles in Service Organizations. Journal of Service Research, 3 (August), 66-81.

Denmon, Denmon Law Firm website (2017). Retrieved from: https://denmon.lawyer/how-we-are-different (23.5.2017). 
Eisenhardt, K.M., Graebner, M.E. (2007). Theory Building from Cases: Opportunities and Challenges. Academy of Management Journal, 50 (1), 25-32.

Gummesson, E. (1978). Towards a theory of professional services marketing. Industrial Marketing Management, 7 (2), 89-95.

Hart, C., Schlesinger, L., Maher, D. (1992). Guarantees come to Professional Service Firms. Sloan Management Review, 33 (Spring), 19-29.

Hausman, A.V. (2003). Professional service relationships: a multi-context study of factors impacting satisfaction, re-patronization, and recommendations. Journal of Services Marketing, 17 (3), 226-242.

Hays, J. (2004). Improving service quality with a service guarantee. Retrieved from: http://www.stthomas.edu/news/improving-servicequality-with-a-service-guarantee (23.5.2017).

Hogreve, J., Dremler, D. (2009). Twenty years of Service Guarantee Research. A synthesis. Journal of Service Research, 11 (4), 322-343.

Jaakkola, E., Halinen, A. (2006). Problem solving within professional services: evidence from the medical field. International Journal of Service Industry Management, 17, 409-429.

Jones, O.J. (1997). Responding to the challenge: a professional services perspective. Facilities, 15 (3/4), 92-96.

Kashyap, R. (2001). The Effects of Service Guarantees on External and Internal Markets. Academy of Marketing Science Review, 5 (8), 1-19.

Maister, D. (1993). Managing the Professional Services Firm. New York: The Free Press.

McLaughlin, M. (2005). Why not guarantee professional services? Retrieved from: http://www.marketingprofs.com/5/mclaughlin6.asp (23.5.2017).

McCullough, M.A. (2010). Service guarantees: a review and explanation of their continued rarity. Academy of Marketing Studies Journal, 14 (2).

Owen, R.S. (2004). Consumer Warranties and Satisfaction Guarantees: Some Definitions and Issues. Services Marketing Quarterly, 26 (2), $49-67$.

Reid, M., (2008). Contemporary marketing in professional services. Journal of Services Marketing, 22 (5), 374-384.

Reihlen, M., Apel, B.A. (2007). Internationalization of professional services as learning - a constructivist approach. International Journal of Service Industry Management, 18, 140-151.

Rogozinski, K. (2000). Nowy marketing usług. Poznań: Wydawnictwo AE.

Schmidt, S. (2004). Marketing the law firm. Business development techniques. New York: Law Journal Press.

Smedlund, A. (2008). Identification and management of high-potential professional services. Management Decision, 46 (6), 864-879.

Sum, C.C., Lee, Y.S., Hays, J.M., Hill, A.V. (2002). Modeling the effects of a service guarantee on perceived service quality using Alternating Conditional Expectations (ACE). Decision Sciences, 33 (3), 347-383.

Thakor, M.V., Kumar, A. (2000). What is a professional service? A conceptual review and bi-national investigation. Journal of Services Marketing, 14 (1), 63-82.

Walsh, K., Gordon, J.R. (2010). Understanding professional service delivery. International Journal of Quality and Service Sciences, 2 (2), 217-238.

Yin, R.K. (2014). Case study research. Design and methods (fifth edition). Thousand Oaks: Sage.

Cite this article aS: Gnusowski, M. (2017). Service guarantees in the context of professional services - case of law firms. European Journal of Service Management, 4 (24), 11-16. DOI: 1.18276/ejsm.2017.24-02. 